\title{
FATHOM
}

\section{Thought and Silence}

The "Pensive Mutes" of Hardy's Verse

Pensée et silence : les «penseurs muets » de la poésie de Hardy

\section{Laurence Estanove}

\section{(2) OpenEdition}

\section{Journals}

Electronic version

URL: http://journals.openedition.org/fathom/397

DOI: $10.4000 /$ fathom.397

ISSN: 2270-6798

Publisher

Association française sur les études sur Thomas Hardy

\section{Electronic reference}

Laurence Estanove, «Thought and Silence », FATHOM [Online], 2 | 2013, Online since 15 September 2013, connection on 19 April 2019. URL : http://journals.openedition.org/fathom/397 ; DOI : 10.4000/ fathom.397

This text was automatically generated on 19 April 2019. 


\section{Thought and Silence}

The "Pensive Mutes" of Hardy's Verse

Pensée et silence : les "penseurs muets » de la poésie de Hardy

\section{Laurence Estanove}

1 In Hardy's poetry, silence comes first and foremost as an obvious mark of absence, of the emptiness left by the loved ones, once departed. As the series to his late wife Emma ( Poems of 1912-13) shows, the poet's painful sense of isolation from the dead is thus signalled by his inability to communicate with them, in spite of their literal haunting presence. Hardy's poetry thus breaks the silence of the dead by letting the mute ghosts speak, what, in a previous article, I have seen as resurrection in the form of a literal evocation - an ex-vocation. Silence, in Hardy's poetry, has therefore an important vocal dimension - but also a structural one, in its relation to rhythm and to punctuation, both participating fully in the constitution and coherence of poetic form itself ${ }^{1}$.

2 Poetical voice and poetical form are indeed my concern here, but rather from the perspective of subjective expression than of orality, though the two cannot be considered separately. Examining the connection between silence and thought thus requires the study of Hardy's own voice in his verse, as poet and as man. Silence leaves space (or time) for reflection: my aim is to demonstrate how, in Hardy's poetical expression, thought precedes and triggers silence, while conversely, silence is proof to the thinking process of an active mind.

3 The starting point of this study is a short sentence from Hardy's notebooks: "I sometimes look upon all things in inanimate Nature as pensive mutes", the author wrote as early in his career as $1876^{2}$. We know that Hardy did indeed consider all things in animate and inanimate nature as endowed with an ability to think and feel. This perception is probably what accounts for the power of landscapes and natural backgrounds in his fiction - recipients of pathetic fallacy because of their ability to feel, and precisely to feel for the fated Hardyan heroes. Hardy's poetry gives a voice to the speechless among the animate $^{3}$ as well as to the purely inanimate, trivial objects thus offered a voice, again, because of their ability to think ${ }^{4}$. Yet this connection between thought and silence has wider implications than what these sometimes frivolous pieces present: on several 
occasions, the poet and writer actually presents himself as a pensive mute, also deprived of voice but not of thought.

Naturally, it might seem inappropriate to say that Hardy, who wrote fourteen or even fifteen novels, more than forty short stories, and almost a thousand poems, had no voice or did not express himself. But not, I would argue, if we look at Hardy's expression of his opinion, at the degree of commitment in his writing, or at the presence of strong unmitigated personal assertions. From that viewpoint, one finds that Hardy's voice is usually elusive. Hardy was extremely sensitive to any criticism of his work; some of his personal notes seem to imply that unfair attacks, misunderstandings, and a more general prudery of the Victorian era made it impossible for him to speak out. This is at least what one can read in the famous note from November 1896 stating that "[i]f Galileo had said in verse that the world moved, the Inquisition might have let him alone" (Hardy 1989, 302) - probably one of the reasons that led him to turn - or return - to poetry at the turn of the twentieth century.

5 It is precisely in poems which bear the trace of a strong personal commitment on Hardy's part, both as poet and as man, that the equation between thought and silence or the tension between judgment and voice is most significant. "Mute Opinion", published in 1901 in Poems of the Past and the Present (Hardy 2001, 127), makes such an equation clear from its very title, confirms it in the bulk of the poem, and even more obviously so in the parallel concluding lines:

$$
\text { Mute Opinion }
$$

I traversed a dominion

Whose spokesmen spake out strong

Their purpose and opinion

Through pulpit, press, and song.

I scarce had means to note there

A large-eyed few, and dumb,

Who thought not as those thought there

That stirred the heat and hum.

when, grown a Shade, beholding

That land in lifetime trode,

To learn if its unfolding

Fulfilled its clamoured code,

I saw, in web unbroken,

Its history outwrought

Not as the loud had spoken,

But as the mute had thought.

The redundancy of loud speech, of publicly professed common opinion ("spokesmen") comes to disturb the quietness and discreetness of the few who hold the truth.

In later poems also, one finds other illustrations of that equation between silence and thought, most particularly - and interestingly - in relation to Hardy's religious beliefs, or unbeliefs - in poems of loss of faith or agnosticism. In Hardy's poetry, the silence of loss is mostly perceptible through the evocation of Emma's absence, as I've previously mentioned. But it is also manifest in the poet's presentation of his agnosticism, and equally in relation to silence. The disappearance of God from Hardy's perspective is indeed almost as harrowing as Emma's absence. Just as the poet notes the emptiness of the places where his wife used to be, so does he focus on the material proofs of God's existence or non-existence: "Jan. 29 [1890]. I have been looking for God 50 years, and I think that if he had existed I should have discovered him. As an external personality, of 
course - the only true meaning of the word" (Hardy 1989, 234). The loss of faith in Hardy is therefore not mere negation or rejection of belief. It is not atheism, but a truly painful agnosticism in its literal sense - the inability to conceive of any given data that is not empirical. That is why when Hardy evokes his agnosticism in his verse, he does so by presenting it as a quest, a fruitless semiotic quest, as clearly stated in "A Sign-Seeker" ( Wessex Poems, 1898; Hardy 2001, 49-50):

\section{A Sign-Seeker}

I mark the months in liveries dank and dry, The day-tides many-shaped and hued; I see the nightfall shades subtrude,

And hear the monotonous hours clang negligently by.

I view the evening bonfires of the sun On hills where morning rains have hissed; The eyeless countenance of the mist Pallidly rising when the summer droughts are done.

I have seen the lightning-blade, the leaping star, The caldrons of the sea in storm, Have felt the earthquake's lifting arm,

And trodden where abysmal fires and snow-cones are.

I learn to prophesy the hid eclipse,

The coming of eccentric orbs;

To mete the dust the sky absorbs,

To weigh the sun, and fix the hour each planet dips.

I witness fellow earth-men surge and strive;

Assemblies meet, and throb, and part;

Death's soothing finger, sorrow's smart;

- All the vast various moils that mean a world alive.

Despite his eager quest and careful observation, the following stanzas offer nothing but the bitter admission of that quest's failure:

But that I fain would wot of shuns my sense Those sights of which old prophets tell, Those signs the general word so well

As vouchsafed their unheed, denied my long suspense.

In graveyard green, where his pale dust lies pent

To glimpse a phantom parent, friend,

Wearing his smile, and "Not the end!"

Outbreathing softly: that were blest enlightenment;

Or, if a dead Love's lips, whom dreams reveal When midnight imps of King Decay

Delve sly to solve me back to clay,

Should leave some print to prove her spirit-kisses real;

Or, when Earth's Frail lie bleeding of her Strong,

If some Recorder, as in Writ,

Near to the weary scene should flit

And drop one plume as pledge that Heaven inscrolls the wrong.

- There are who, rapt to heights of trancelike trust,

These tokens claim to feel and see,

Read radiant hints of times to be -

of heart to heart returning after dust to dust.

9 The end of the poem makes it clear that this sign-seeking is also a quest for voices, a calling of voices which remains unanswered:

Such scope is granted not to lives like mine...

I have lain in dead men's beds, have walked 
The tombs of those with whom I'd talked,

Called many a gone and goodly one to shape a sign,

And panted for response. But none replies;

No warnings loom, nor whisperings

To open out my limitings,

And Nescience mutely muses: When a man falls he lies.

Waiting for an answer leaves the poet gasping, in utter silence, in a state of anxious suspense ("panted for response") made literal by the run-on line from one stanza to the next, and abruptly ended by the sharp caesura which follows. There is silence here, also, in the ellipsis following the poet's admission of his limited scope. And there is, again, the mute opinion explicitly associated with agnosticism, in the equation between thought and silence of the alliterative "mutely muses". Indeed, it is precisely in the experience of the religious service, as he recorded it also in his notebooks, that Hardy seemed to perceive with the bitterest sense of dejection the absurdity of faith in a world deprived of signs. This is obvious in a note from January 1907:

We enter church, and we have to say; 'We have erred and strayed from thy ways like lost sheep', when what we want to say is, 'Why are we made to err and stray like lost sheep?' Then we have to sing, 'My soul doth magnify the Lord', when what we want to sing is, ' $O$ that my soul could find some Lord that it could magnify! Till it can, let us magnify good works, and develop all means of easing mortals' progress through a world not worthy of them.'

Still, being present, we say the established words full of the historic sentiment only, mentally adding, 'How happy our ancestors were in repeating in all sincerity these articles of faith!' But we perceive that none of the congregation recognizes that we repeat the words from an antiquarian interest in them, and in a historic sense, and solely in order to keep a church of some sort afoot - a thing indispensable; so that we are pretending what is not true; that we are believers. This must not be; we must leave. And if we do, we reluctantly go to the door, and creep out as it creaks complainingly behind us. (Hardy 1989, 358)

11 We understand at the end of the note that "we" is actually the "I" of the writer, as opposed to the rest of the congregation; and therefore the parallel structures of the beginning of the note truly show how the writer is torn between the necessity of ritual speech or singing, and the muted opinion or thought he is left with.

In Wessex Poems, "A Sign-Seeker" was hinting at the poet's agnosticism. "The Impercipient", another poem from the same collection (Hardy 2001, 67-68), makes the reference even more explicit, by precisely describing the agnostic's experience of a religious ceremony in a tone very similar to that of the previous note.

The Impercipient

(At a Cathedral Service)

That with this bright believing band

I have no claim to be,

That faiths by which my comrades stand

Seem fantasies to me,

And mirage-mists their Shining Land, Is a strange destiny.

why thus my soul should be consigned

To infelicity,

Why always I must feel as blind

To sights my brethren see,

Why joys they've found I cannot find, Abides a mystery. 
Since heart of mine knows not that ease Which they know; since it be

That He who breathes All's Well to these Breathes no All's-Well to me,

My lack might move their sympathies And Christian charity!

I am like a gazer who should mark An inland company

Standing upfingered, with, 'Hark! Hark! The glorious distant sea!'

And feel, 'Alas, 'tis but yon dark And wind-swept pine to me!'

Yet I would bear my shortcomings With meet tranquillity,

But for the charge that blessed things I'd liefer not have be.

0 , doth a bird deprived of wings Go earth-bound wilfully! ...

Enough. As yet disquiet clings About us. Rest shall we.

The explicit subtitle defines the specific context of the piece, a frame that the illustration of the poem (Hardy's own illustration for the first edition of Wessex Poems) also sets up more palpably.

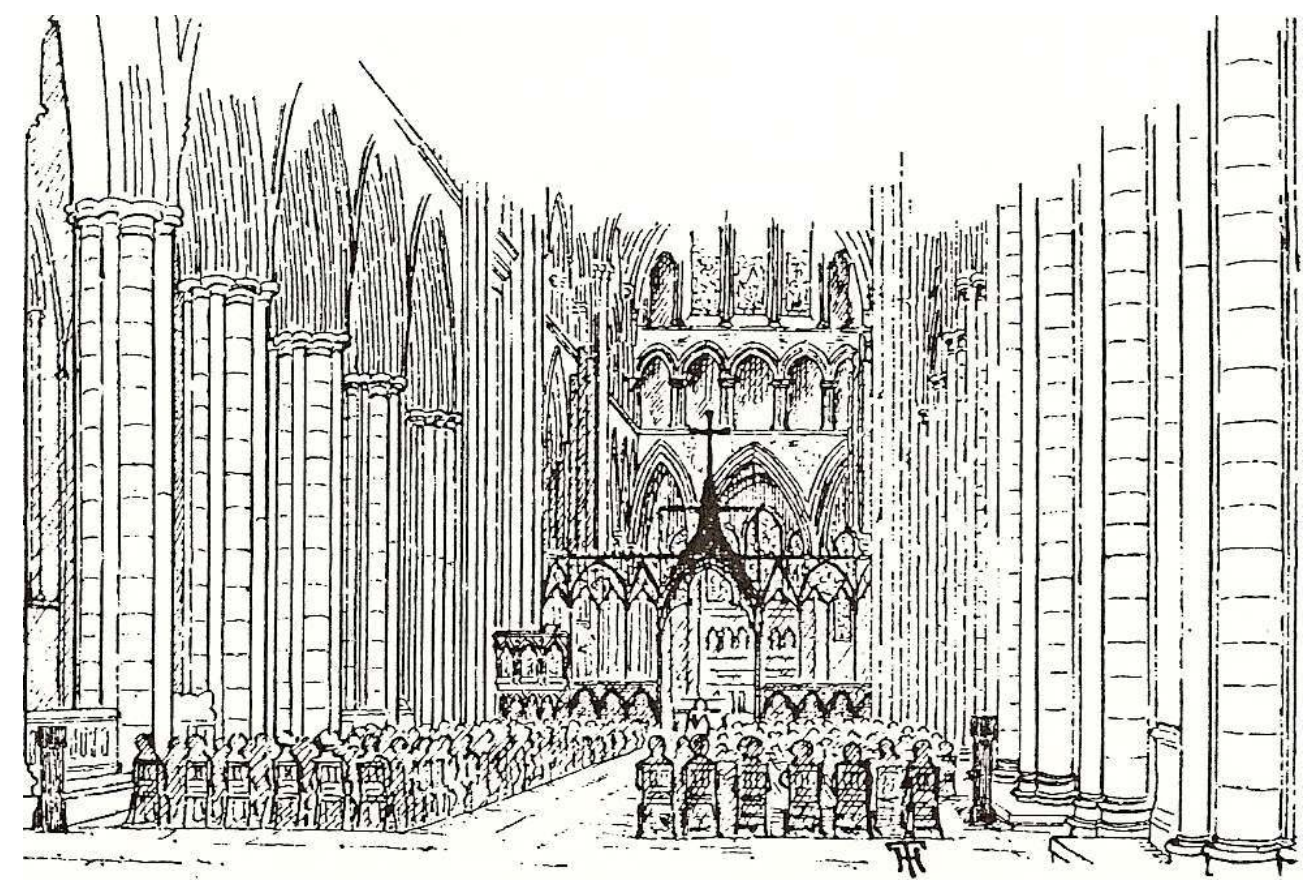

"THE IMPERCIPIENT" (ILLUSTRATIONS 153)

Hardy took inspiration for that drawing from the interior of Salisbury Cathedral of which he was a frequent visitor. The anonymous docile crowd seems to be lost in the array of vertical lines. The viewpoint is therefore Hardy's own rather than the congregation's, and thus clearly that of an outsider observer, "a gazer who should mark an inland company". The original title for the poem, "The Agnostic", was even clearer as to the argument presented; the change to "Impercipient" shifts attention from loss of faith to perceptive impairment, something I shall come back to. Bailey explains how genuinely 
autobiographical that poem was: "[Hardy's] wish to believe, his sense of isolation from the 'bright believing band', was not strong enough to make him will to believe in spite of the evidence as he saw it. The poem expresses his distress that both the critics who attacked him for unbelief, and his friends, whom his agnosticism hurt, did not fully see that he could not accept their faith" (Bailey 103).

The constant shift from I to they points to the poet's isolation as the argumentative core. As in the note from 1907, the congregation's loudly expressed belief, which the poem opens with, collides with the poet's forced silence ("Enough"), significantly added as a snapping coda. Hardy ends his poem abruptly, just as his agnostic views need to be silenced in the face of surrounding criticism ("disquiet clings / About us").

A similar tension between silent thought and clamorous speech appears again in a later poem, one of Hardy's numerous "philosophical" pieces which dramatize God's indifference, Nature's cruelty, or the loss of faith. The poem "God's Funeral" (Satires of Circumstance, 1914; Hardy 2001, 326-329) thus sets up an ironical dramatization of the Nietzschean idea of the death of God. The poem opens with the speaker meeting a crowd of grieving people whom he starts to follow. Significantly, he remains silent while the rest voice out their grief at the loss of God, as stanza $\mathrm{V}$ specifically shows:

Almost before I knew I bent

Towards the moving columns without a word;

They, growing in bulk and numbers as they went,

Struck out sick thoughts that could be overheard

Further down in the poem, in stanza XIV which recalls the "Impercipient"'s coda, the agnostic speaker is forced to silence ("struck speechless") both by a deep feeling of sympathy for the mourners, and by the sense of his exclusion from the group:

I could not buoy their faith: and yet

Many I had known: with all I sympathized;

And though struck speechless, I did not forget

That what was mourned for, I, too, long had prized.

"I" is here again clearly cast off from the rest, from the crowd: it is in fact, almost paradoxically, the very juxtaposition of the first-person pronoun with the collective nouns "many" and "all", which points at the speaker's exclusion from that group.

Quite often in Hardy's verse, it is the most personal and intense writing which conveys this sense of exclusion of the poet, as for instance in the poem "In Tenebris". Written around 1895 and published in 1901 in Poems of the Past and the Present (Hardy 2001, 167-169), this threefold piece offers an agonizing evocation of the poet's depression of the 1890 s, and is probably one of the darkest Hardy wrote. The second part is the most eloquent as to the isolation the poet feels:

In Tenebris II

When the clouds' swoln bosoms echo back the shouts of the many and strong

That things are all as they best may be, save a few to be right ere long,

And my eyes have not the vision in them to discern what to these is so clear,

The blot seems straightway in me alone; one better he were not here.

The stout upstanders say, All's well with us: ruers have nought to rue!

And what the potent say so oft, can it fail to be somewhat true?

Breezily go they, breezily come; their dust smokes around their career,

Till I think I am one born out of due time, who has no calling here.

Their dawns bring lusty joys, it seems; their evenings all that is sweet;

Our times are blessed times, they cry: Life shapes it as is most meet, 
And nothing is much the matter; there are many smiles to a tear;

Then what is the matter is I, I say. Why should such an one be here? ...

Let him in whose ears the low-voiced Best is killed by the clash of the First, Who holds that if way to the Better there be, it exacts a full look at the Worst,

Who feels that delight is a delicate growth cramped by crookedness, custom and

fear,

Get him up and be gone as one shaped awry; he disturbs the order here.

(emphases added)

20 Again, what opposes the poet to the "many and strong" seems to be, among other things, a matter of voice - their claims, their cries and loudness. Common opinion thus expresses itself via noise and excess, and indeed, in the poems mentioned previously, figures of excess are also used to evoke the boisterousness of the "many and strong". In "A Sign-Seeker", believers are "rapt to heights of trancelike trust", a hyperbole made even more eloquent by the alliterations in / $t$ / that seem to mechanize speech. In "Mute Opinion", similarly, initial alliteration combines with the redundancy of a polyptoton to convey the inane loudness of speech ("a dominion / Whose spokesmen spake out strong").

The failure of the agnostic's semiotic quest is, as I have previously explained, revealed by the poet's inability to perceive what the others see as signs of God's existence. This impairment is precisely what gives "The Impercipient" its title, and it is also often presented as an actual blindness: "Why always I must feel as blind / To sights my brethren see", "A Sign-Seeker" thus concludes. In "In Tenebris", the weakness is more precisely presented as a "blot", thus signalling the truly palpable physical quality of the poet's anxiety at not perceiving what all the others see.

And yet, this stance might actually be but mere pretence and irony from the poet's part which is hardly surprising in the case of Hardy. There's an ironical reversal of viewpoint because the mute and blind agnostic is also presented in several poems as a visionary. "Mute Opinion" already hinted at the visionary powers of the pensive mutes, a "largeeyed few" able to predict the unfolding of history. Eventually, in one of his last poems, the aptly named "He Resolves to Say No More" (Winter Words, 1928; Hardy 2001, 929-930), Hardy uses pretence again - even bordering on paralipsis - to openly assert his belief in the visionary powers of the mute, and more precisely in his own clear-sightedness:

He Resolves to Say No More

O my soul, keep the rest unknown!

It is too like a sound of moan

When the charnel-eyed

Pale Horse has nighed:

Yea, none shall gather what I hide!

Why load men's minds with more to bear

That bear already ails to spare? From now alway Till my last day

What I discern I will not say.

Let Time roll backward if it will;

(Magians who drive the midnight quill With brain aglow Can see it so,)

What I have learnt no man shall know.

And if my vision range beyond

The blinkered sight of souls in bond, - By truth made free - 
I'll let all be,

And show to no man what I see. surest means for protection against criticism, it is no longer so for the experienced disillusioned poet of "He Resolves to Say No More". Silence is thus finally not imposed on the poet's view, but entirely endorsed. Instead of being "struck speechless" by his own unconventional opinion, the poet finally seems to embrace muteness as his mode of expression.

\section{BIBLIOGRAPHY}

Bailey, J. O., The Poetry of Thomas Hardy: A Handbook and Commentary, Chapel Hill: U of North Carolina P, 1970.

Estanove, Laurence, “'Voices From Things Growing in a Churchyard': Hardy's verse on both sides of the grave", The Hardy Society Journal 4.2 (Summer 2008): 29-39.

Estanove, Laurence, “A Lament and a Sigh: Voicing Disillusionment in Thomas Hardy's Verse”, The Hardy Review 11.1 (Spring 2009): 31-40.

Estanove, Laurence, “Rhythm in Thomas Hardy's Verse: 'New Continuities of Meaning”, Études Britanniques Contemporaines 39 (décembre 2010): 35-49.

Hardy, Thomas, The Life and Work of Thomas Hardy, ed. Michael Millgate, London: Macmillan, 1989.

Hardy, Thomas, The Complete Poems, ed. James Gibson, Basingstoke: Palgrave, 2001.

"Illustrations for Wessex Poems", Victorian Poetry 17.1/2, "The Poetry of Thomas Hardy: A

Commemorative Issue" (Spring-Summer, 1979): 135-154.

FATHOM, 2 | 2013 


\section{NOTES}

1. I have previously published three articles on very similar subjects, see bibliography.

2. Notebook entry from 30 May 1876 (Hardy 1989, 117).

3. I'm thinking for example of the speaking animals and insects of pieces such as "The Caged Thrush Freed and Home Again" (Poems of the Past and the Present, 1901; Hardy 2001, 147) or "The Lizard" (uncollected, published separately in 1915; Hardy 2001, 952).

4. Such are the incongruous personae of "The Sundial on a Wet Day" (Human Shows, 1925; Hardy 2001, 808-809) or "The Letter's Triumph" (Winter Words, 1928; Hardy 2001, 898-899).

\section{ABSTRACTS}

In Hardy's poetry, silence comes first and foremost as an obvious mark of absence, of the emptiness left by the loved ones, once departed. As Poems of 1912-13, the series of poems to his late wife Emma, shows, the poet's painful sense of isolation from the dead is thus signalled by his inability to communicate with them. Poetry thus breaks the silence of the dead by letting the mute ghosts speak, and beyond that, by giving the speechless and the inanimate - "pensive mutes" - a voice, from insects and animals to trivial objects, incongruous personae of various poems. In reality, the poet and writer also presents himself as a pensive mute, deprived of voice but not of thought, "struck speechless" by the survival of dogmas but still retaining his personal reflexion. The equation between thought and silence or tension between judgment and voice thus appears in several poems which bear the trace of a strong personal commitment on Hardy's part, both as poet and as man - poems of agnosticism such as "God's Funeral", "The Impercipient" and "A Sign-Seeker". The silence imposed on Hardy's agnostic views points again at the poet's isolation, cast off as he is by his loss of faith. Central to the ambiguity of thought and silence in Hardy's verse is the use of irony and pretence, as one of Hardy's last poems makes it clear: "He Resolves to Say No More".

Dans la poésie de Hardy, le silence se présente tout d'abord comme marque évidente de l'absence et du vide laissé par la disparition des êtres chers. Ainsi qu'on peut le lire dans Poems of 1912-13, série de poèmes que Hardy compose à la mort de sa première épouse Emma, le poète vit cette séparation comme un douloureux isolement, et tente alors par le biais de l'écriture de redonner une voix à ceux que la mort a rendus silencieux. Mais par la diversité des voix poétiques qui se font entendre dans son œuvre, il offre également la parole à ces "penseurs muets" que sont les animaux ou les objets. La correspondance entre silence et pensée semble en vérité tout à fait caractéristique de son écriture, puisque c'est lui-même, poète et homme, qu'il met en scène à plusieurs reprises comme penseur muet, frappé de mutisme face à la persistance des dogmes ou à l'impossibilité de donner voix à son agnosticisme. La tension entre voix et jugement apparaît ainsi dans de nombreux poèmes qui relaient les souffrances et l'isolement de celui qui a perdu la foi, poèmes tels que "God's Funeral”, “The Impercipient” et "A Sign-Seeker”. Chez Hardy, de manière typique, ce sont l'ironie et le faux-semblant qui viennent relayer toute l'ambivalence de cette relation entre pensée et silence, comme en témoigne également l'un des tout derniers poèmes, "He Resolves to Say No More". 


\section{INDEX}

oeuvrecitee Pensive Mutes, Mute Opinion, God's Funeral, Impercipient (The), Sign-Seeker (A), He Resolves to Say No More, Caged Thrush Freed and Home Again (The), Lizard (The), Sundial on a Wet Day (The), Letter's Triumph (The), Poems of the Past and the Present, Wessex Poems

Mots-clés: poésie, silence, pensée, voix, mutisme, agnosticisme, isolement, ironie

Keywords: poetry, silence, thought, voice, muteness, agnosticism, isolation, irony

\section{AUTHOR}

\section{LAURENCE ESTANOVE}

Université Paris-Descartes / Université de Toulouse - CAS

Professeur agrégée

Docteur en études anglophones 